\title{
WEALTH ACCUMULATION OF CANADIAN AND FOREIGN-BORN HOUSEHOLDS IN CANADA
}

\author{
By Abul F. M. Shamsuddin \\ University of New England \\ and \\ DON J. DEVORETZ \\ Simon Fraser University
}

\begin{abstract}
This study focuses on the role of foreign-born households in Canada's asset market. An empirical analysis of wealth accumulation is conducted for a large sample of Canadian households circa 197784. This study period reflects a change in Canada's immigration policy which resulted in immigration flows switching from Europe to Asia. A life-cycle framework is used to examine wealth accumulation behaviour of the foreign-born vis-à-vis Canadian-born households. The empirical results confirm the existence of an inverted ' $U$ '-shaped wealth-age profile for both Canadian and immigrant households. However, the 1977 results show that the rate of wealth accumulation is higher for the immigrant household than the Canadian-born household in pre-retirement years, while the 1984 results reveal the opposite. After retirement, the rate of wealth dissipation is slower for Canadians than for foreignborn households. Only the 1984 results indicate that public social security wealth displaces household savings for both the Canadian-born and the foreign-born by a small amount. Finally, an immigrant household exhibits a stronger transfer motive within a family than a Canadian-born household regardless of year tested.
\end{abstract}

\section{INTRODUCTION}

Given that the post-1977 rise in Canada's immigration intake was partially predicated on the presumption that immigrants could help raise Canada's relatively low private savings rate, this paper investigates the potentially differential wealth accumulation behaviour of Canadian- and foreign-born households. ${ }^{\prime}$ The impact of old age social security programmes on the savings behaviour of both Canadian- and the foreign-born households is also evaluated. In general, previous immigration research has focused on the immigrants' labour market performance and hence ignored the role of immigrants in the capital market (see DeVoretz, 1993). The present study intends to fill this gap in the literature.

There exist a priori reasons to believe that foreign-born savings behaviour may differ from that of the Canadian-born. First, immigrants are not a random sample drawn from abroad. Indeed, the foreign-born are doubly selected. At the first stage, immigrants self select and participate in a worldwide immigration

Note: The authors are grateful to two anonymous referees for constructive comments.

'Canada's aggregate savings rate averaged $20.7 \%$ in the 1980 s down from $23 \%$ in the 1970 s. The household sector is the principal source of Canadian savings $(12.5 \%)$. Over the last three decades, the corporate savings rate has remained stable $(8.5 \%)$ while public savings became negative and private household savings rose. (Source: OECD National Income Accounts, compiled by Shafer, Elmeskov and Tease, 1992). 
market. At the second stage, from this pool of self-selected agents Canada selects immigrants partially based on labour market and demographic criteria. Thus, given these economic entry criteria, the income performance and hence household intertemporal budget restraint may differ in Canada by birthplace. Second, some immigrants have limited access to Canada's federal old age security (OAS) pension since entitlement to OAS pension is linked to age and residency and not means tested. ${ }^{2}$ This public pension represents a unique non-marketable indexed annuity that has no close substitute in the private annuity market. This differential access to Canada's old age social security programme imposes a different constraint on the wealth accumulation decisions of immigrants vis-à-vis Canadian-born households. Third, Canada's immigration policy changed over the study period with source countries moving from Europe to Asia. Thus, the tastes, preferences and cultural and economic backgrounds of immigrants have become increasingly diverse from the Canadian-born population and this in turn may yield differential saving propensities by birthplace.

The paper is organised as follows. The next section reviews the literature. Section 3 examines the implications of a general life-cycle model for wealth accumulation profiles of immigrants vis-à-vis Canadian-born households. Section 4 provides the empirical model and describes the data. The empirical results are analysed in Section 5. The final section presents a summary and draws policy implications.

\section{Literature Survey}

Explanations for household savings have a long history in the literature with one dominant strain arguing that households use capital markets to smooth consumption over their life cycle. This theory suggests that despite large fluctuations in disposable income, the level of consumption remains reasonably stable over an individual's lifetime. On the other hand, human-capital theory suggests that a typical individual's age-income profile follows an inverted U-pattern. This income and consumption behaviour together imply a hump-shaped wealth-age profile. Even in the absence of a quadratic earnings profile, wealth accumulation will follow an inverted U-pattern as long as labour income ceases at retirement.

Support for the U-shaped wealth-age profile in Canada is provided by Burbidge and Robb (BR, 1985) who investigated the asset accumulation behaviour of major household groups in Canada (blue-collar versus white-collar) using 1977 consumer finance data. Their results suggest that an inverted U-shaped wealth age profile exists in general. However, they note that "blue-collar" households dissave after retirement, while "white-collar" households do not.

An alternative method to explain household wealth holdings is to analyze the underlying consumption-age profiles. The general premise of an upward-sloping consumption-age profile and consequently dissaving in retirement (Auerbach and Kotlikoff, 1987) is not, however, supported by two recent Canadian studies. Robb and Burbidge (1989) found that consumption-age profiles were downward sloping late in the life cycle. Using Family Expenditure Survey data $(1979,1983,1984)$,

\footnotetext{
${ }^{2}$ Individuals with at least 40 years of residence in Canada are eligible for full OAS benefits.
} 
Marr and McCready (1989) also found a sharp decrease in consumer spending on all items and an increase in savings for the over-age- 65 cohort.

Feldstein's studies $(1974,1977)$ analyze the impact of social security benefits on private savings. He argued that social security resulted in a "wealth replacement effect" and a countervailing "induced retirement effect." The former implies that social security reduces private wealth accumulation by providing income during retirement. A countervailing effect of social security arises from the possibility that social security, by providing non-labour income, induces the elderly to reduce their labour supply. If an individual perfectly anticipates this reduction in labour supply, wealth accumulation over his/her working life span will increase. Thus, the net effect of a social security programme on private net worth is theoretically indeterminate. Feldstein's (1974) empirical results indicate that a dollar increase in gross social security wealth (SSW) raised the aggregate consumption in the U.S. by two cents which implies a fall in savings, ceteris paribus.

Boyle and Murray (1979) estimated a Feldstein-type model to measure with time series data the net impact of the Canada Pension Plan on Canadian household savings. They report no statistically significant effect of Canada's public pension plans on household savings. Finally, King and Dicks-Mireaux (KDM, 1982) examined the interaction of social security wealth and private wealth-age profiles with Canadian cross-sectional data (1977). The KDM study reported: (i) an inverted U-shaped wealth-age profile with a slow rate of wealth dissipation in retirement; and (ii) that social security and pension benefits reduce household savings, ceteris paribus.

In sum, the Canadian work to date provides empirical support for a qualified version of the life-cycle model of accumulation, which recognizes the impact of uncertain life-span and the presence of a transfer motive.

\section{Conceptual Framework}

This section presents a conceptual framework to explain differential immigrant- and Canadian-born household wealth accumulation behaviour. More specifically, we first identify factors that determine household wealth accumulation and then argue that both the endowment of these factors and an individual household's savings response to these factors may differ by birthplace.

The pure life-cycle model signifies the importance of wealth accumulation during working life-span for consumption during retirement. This postulated lifetime savings pattern may vary across households due to differences in age, initial asset holdings, magnitude of earning streams, time preferences (or tastes), and the size and composition of household. However, a feature common to all household accumulation profiles is the proposition that "[W]ealth must clearly be declining after retirement, and at a sufficiently fast pace to reach exhaustion at the end of life (Modigliani, 1988: 23)." We have noted above contrary evidence to this prediction in some Canadian and U.S. cross-section studies (see last section) that reveals a very slow rate of wealth dissipation for the elderly.

Given this crucial shortcoming of terminal wealth dissipation, attempts have been made to extend the life-cycle model in three key directions to produce more 
realistic predictions. These extensions include: the incorporation of public annuities in the household budget constraint (Feldstein, 1974, 1977); recognition of a transfer motive (bequests and inter vivo transfers) within the family (e.g., Blinder, 1973) and the inclusion mortality risk in the model (e.g., Davies, 1981; and Hurd 1989).

Feldstein provides us with a framework to analyse whether or not the impact of Canada's social security wealth on private wealth accumulation differs by birthplace. An obvious implication of the pure life-cycle model is that, by providing income during retirement life span, an actuarially fair social security programme reduces private wealth accumulation. Put differently, a wealthreplacement effect arises under an actuarially fair social security programme as the household substitutes dollar-for-dollar public-for-private capital. On the other hand, social security, which provides income to the aged, reduces labour supply during retirement. A further reduction in labour supply may occur if the magnitude of social security benefits depends on an earnings test. This test reduces labour supply of the aged by imposing an implicit tax on their earnings. If this reduction in labour supply over the late stage of the life cycle is correctly anticipated by workers, private savings during the pre-retirement life span may increase. Feldstein termed this the "induced retirement effect." The net effect of old age social security on private wealth is theoretically indeterminate because the induced retirement effect operates in an opposite direction to the wealth replacement effect.

Blinder (1973) modified the life-cycle theory of accumulation by including a transfer or bequest motive to help explain the slow rate of wealth dissipation for the elderly. One likely outcome of this model is presented in Figure 1. The optimal consumption, $C^{*}(L)$ depends on the household's lifetime resources net of present value of desired bequests. $C^{*}(L)$ is upward sloping in the stage of life cycle $(L)$ if the household's subjective time rate of discount is smaller than the market interest rate. The corresponding wealth-age profile, $W^{*}(L)$ is likely to be an inverted-U shaped providing that initial wealth $\left(b_{0}\right)$ is not large and/or earnings $(E)$ cease at retirement $(N)$. The desired bequests in this model are an increasing function of lifetime resources and the marginal utility from bequests.

Uncertainty over time of death or mortality risk will also affect the rate of wealth dissipation. Hurd (1989) provides a model, under which individuals derive utility from consumption and bequests under an uncertain date of death. ${ }^{3}$ In general, an increase in mortality risk increases present consumption at the expense of future consumption, given some degree of risk aversion to mortality. ${ }^{4}$ In sum, Hurd provides two theoretically relevant findings for this paper: (i) the wealthage profile for the elderly is downward sloping unless initial wealth is too large,

\footnotetext{
${ }^{3}$ Households finance their consumption and bequests from non-labour income flowing from initial wealth (net worth at the beginning of the planning period) and exogenously given annuities which can not be used as collateral for borrowing. The latter imposes a boundary condition on the desired paths of consumption and wealth. Another important determinant of those paths is the mortality risk.

${ }^{4}$ Hurd (1989) observes a moderate degree of mortality risk aversion from the U.S. Longitudinal Retirement History Survey. He also finds a small marginal utility from bequest, implying a small amount of desired bequests. Thus, most bequests are accidental-an outcome of mortality risk.
} 

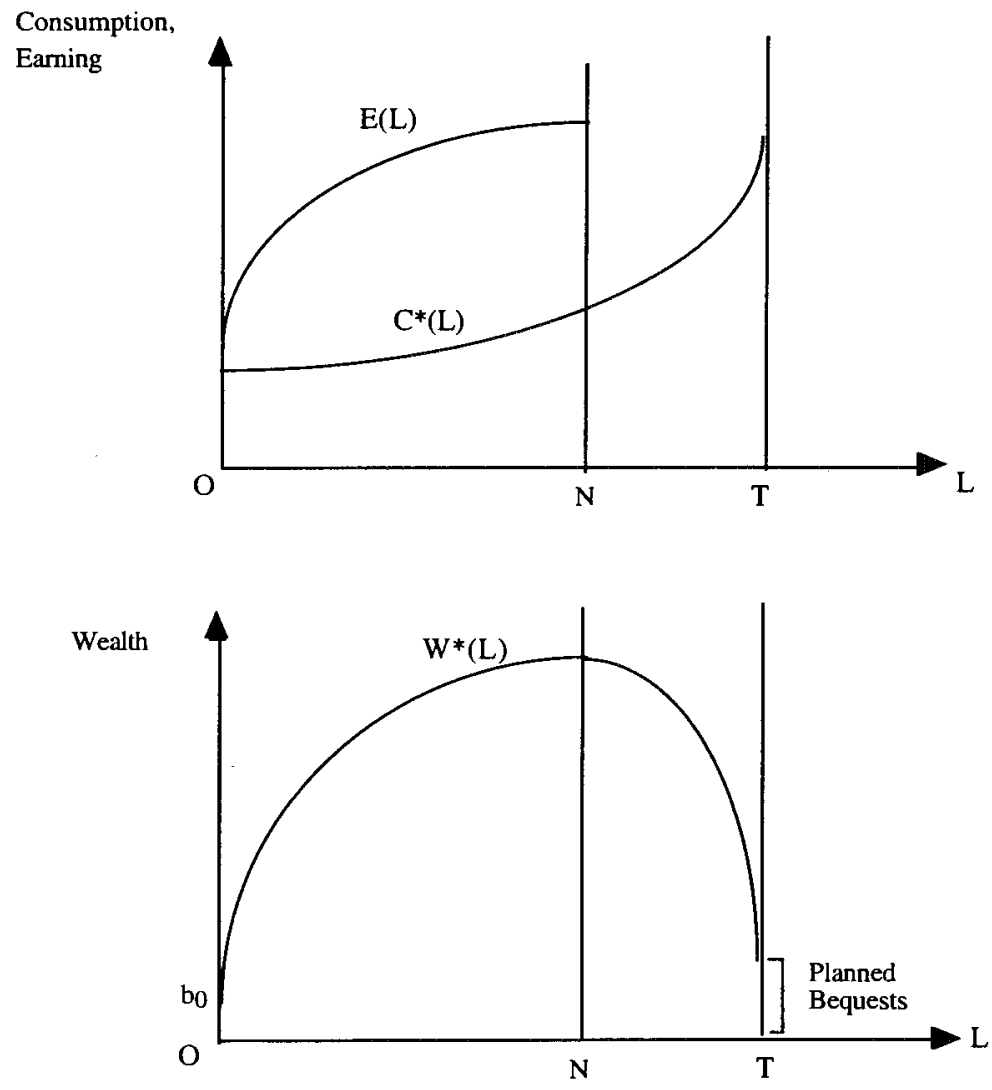

Figure 1. Life-cycle earnings, consumption and wealth profiles

and (ii) the introduction of a bequest motive makes the wealth-age profile flatter over the retirement life.

\section{Implications for Wealth Accumulation Profiles of Immigrants vis-à-vis Canadian- Born Households}

The above conceptual framework implies that the optimal wealth holdings of immigrants may differ from those of the Canadian-born due to the following basic reasons:

(i) differences in the endowment of household characteristics such as lifetime resources (inheritance, earnings profile and annuities), the stage in the household's life cycle and mortality risk; and

(ii) differences in household tastes and preferences, which are crucial in determining the sensitivity of wealth accumulation with respect to each of the above observed factors, and

(iii) differences in eligibility to Canada's publicly financed social security programmes. 
We expand on the explanations of these differential features below. Household lifetime resources depend mainly on inheritance or initial assets, their earning profile and annuities. Each of these elements may differ by birth status.

First, given that immigrants are by definition a first generation resident population in Canada, their inheritance or initial assets at the beginning of Canadian economic life will be lower than the Canadian-born population. ${ }^{5}$

Second, unlike the Canadian-born population, the foreign-born population has limited access to one component of Canada's social security programme due to the existence of a residency test. The old age social security system in Canada includes three key programmes: the Canada/Quebec pension plan (CPP/QPP), Old Age Security Pension (OAS), Guaranteed Income Supplements (GIS) and Spouse Allowance (SPA). The CPP/QPP is a mandatory public pension programme for all workers which provides an annuity based on the earnings history of the individual; the OAS pension is subject to the age and residency test; the GIS provides benefits to OAS eligible pensioners subject to a means test, and finally, the SPA benefit is also means tested and targeted to the spouse (aged 60 65 years) of a pensioner. Thus, overall entitlement to social security benefits depends on age, years of residence in Canada, household characteristics (e.g., spouse's age), income and social security rules. Due to the residency test, an immigrant may receive little or no OAS pension. ${ }^{6}$

A third differential force impacts on the foreign-born population uniquely in the form of a transitional effect. Most immigrants enter Canada either at the last stage of their schooling period or after the completion of formal education (Coulson and DeVoretz, 1993) but they continue to invest in order to acquire further human capital that is specific to the Canadian labour market (e.g., language proficiency, formal education, vocational training, firm-specific training etc.). Thus, the earnings profile of a typical immigrant will initially fall short but ultimately catch up to the earnings profile of a typical Canadian-born. ${ }^{7}$ In spite of initial low earnings, an immigrant usually spends a large fraction of this income on consumer durables at the early stage of his/her Canadian life cycle. Consequently, the wealth accumulation profile of an immigrant household is likely to lie below that of a comparable Canadian-born household at the initial stage of settlement.

\footnotetext{
${ }^{5}$ This argument may not hold for the foreign-born population who entered Canada as children and then formed households.

${ }^{6}$ The implications of the residency test for OAS is the following: immigrants, who arrived Canada at age 25 or less will be entitled to full OAS benefits; immigrants, who arrived Canada at age between 26 and 55 will be entitled to partial OAS benefits; and immigrants arrived Canada after age 55 will not be entitled to OAS benefits.

${ }^{7}$ Qualifying this human capital interpretation is the claim that individual earnings are not only a function of an individual's human capital endowment, but also of characteristics that are inscribed (rightly or wrongly) to the ethnic group to which they belong. In short, if employers believe that immigrants have a smaller endowment of human capital specific to the Canadian labour market and therefore are less productive on average, then birth status may serve as a low-cost screening device. Consequently, immigrants whose productivity characteristics are above average or equivalent to native-born workers will be subjected to so called statistical discrimination. In sum, differential ageearnings profiles arise due to both endowment differentials and labour market discrimination. See Shamsuddin (1997) for empirical evidence on the combined effect of birthplace and gender on earnings in Canada.
} 
Fourth, in addition to the pure transitional effect, a persistent difference in wealth accumulation between the foreign- and Canadian-born households arises from the double selection of immigrants (see Section 1) and the resulting differential unobserved skills and innate abilities between foreign-born vis-à-vis the Canadian-born.

Finally, the accumulation profile will vary by birth status if the foreign-born household possesses a different rate of time preference, greater (or less) mortality risk aversion and varying tastes for in vivo versus end of life transfer (bequests). For example, it is widely believed that immigrants originating from Asian countries have a stronger preference than the Canadian-born for intergenerational transfers within the extended family unit. Thus, these immigrants may exhibit a different accumulation profile, ceteris paribus, to achieve transfer goal at the end of their lives.

These sources of differences in the characteristics of the foreign-born population are reinforced by major post-1967 Canadian immigration policy changes. In 1967, Canada introduced a points system (based on education, occupation, experience, age etc.), which replaced "country of origin" as a selection criterion and later (post-1977) relaxed family reunification rules. Table 1 illustrates the effect of these policy changes as Canada's immigrant intake shifted from Western Europe to Asia. ${ }^{8}$ Two fundamental changes resulted from the policy shift after 1976: first, immigrant-source countries shifted. For example, the $1978-86$ immigrant flow from Asia and other underdeveloped countries constituted 49 percent of Canada's arrivals. This portion was only 5.5 percent of arrivals prior to 1967 . Secondly, the ethnic composition of Canada's foreign-born population differed

TABLE 1

Population by Ethnic Origin, 1986 Census (in percentage)

\begin{tabular}{|c|c|c|c|c|c|c|c|}
\hline & British & French & $\begin{array}{c}\text { Other } \\
\text { European }\end{array}$ & Asiatic & $\begin{array}{l}\text { Aboriginal } \\
\text { Black \& } \\
\text { Caribbean }\end{array}$ & Other & $\begin{array}{c}\text { Row } \\
\text { Total }^{\text {at }}\end{array}$ \\
\hline \multicolumn{8}{|l|}{ Birthplace Group } \\
\hline $\begin{array}{l}\text { Canadian-born } \\
\text { Married persons }\end{array}$ & 46.5 & 32.1 & 11.3 & 0.3 & 1.3 & 8.3 & $100.0(188,076)$ \\
\hline $\begin{array}{l}\text { Foreign-born } \\
\text { Married persons }\end{array}$ & 26.8 & 2.7 & 45.8 & 16.6 & 2.8 & 5.3 & $100.0(51,817)$ \\
\hline \multicolumn{8}{|c|}{$\begin{array}{l}\text { Period of Immigration } \\
\text { to Canada }\end{array}$} \\
\hline Before 1946 & 51.0 & 4.5 & 39.3 & 1.2 & 0.1 & 3.9 & $100.0(4,617)$ \\
\hline $1946-67$ & 27.1 & 2.6 & 61.1 & 4.6 & 0.9 & 3.7 & $100.0(26,140)$ \\
\hline $1968-77$ & 22.3 & 2.4 & 31.6 & 30.2 & 6.4 & 7.1 & $100.0(13,447)$ \\
\hline $1978-86$ & 18.0 & 2.4 & 22.7 & 44.4 & 4.6 & 7.9 & $100.0(7,447)$ \\
\hline
\end{tabular}

Note: Sample proportions are calulated from the Public Use Sample Tape for 1986 Canadian Census.

"The figure in parenthesis represents the number of observations in each cohort.

${ }^{8}$ The data set used for econometric analysis does not contain information on ethnic origin or country of birth. Thus, extraneous information based on the 1986 Census family file are presented in Table 1. 
significantly from that of the Canadian-born population by 1986. Asian's constituted 16.6 percent of the foreign-born population and only 0.3 percent in the Canadian-born population. These changes in source countries by level of development and ethnic mix imply differences in taste and preferences and possibly differential wealth accumulation rates by birthplace.

\section{Empirical Specification and the Data}

\section{The Empirical Model}

The conceptual framework presented in the last section suggests that desired wealth holding depends on lifetime earnings, age, the interest rate and preference parameters. The study uses 1977 and 1984 Survey of Consumer Finance (SCF) data to estimate the parameters of the empirical model. ${ }^{9}$ Given that this study uses cross-sectional data, it is impossible to estimate the interest rate effect because all sample members face a uniform market rate. Furthermore, lifetime earnings can only be computed from the earnings history of an individual over his/her life cycle. Hence, an estimate of the household's normal earnings is used to capture the effect of lifetime earnings on desired household wealth holding. ${ }^{10}$ With respect to the transfer motive, an earlier theoretical analysis (see Shamsuddin, 1993) suggests that the desired transfer wealth is a proportion of lifetime resources where the proportion varies with the length of life, tastes and the interest rate. The most important determinant of the taste for transfer wealth has been argued to be the number of children. Blinder et al. (1983) expressed desired transfer wealth as a quadratic function of the number of children. They hypothesized that transfer wealth increases at a decreasing rate as the number of children increases. The present study adopts this specification since both the life cycle and the transfer motives are competing for lifetime resources.

Theoretically, household wealth can be partitioned into life-cycle wealth $\left(W_{L}\right)$ and intergenerational transfer wealth $\left(W_{\mathrm{B}}\right)$. Households are not asked to declare wealth holdings by accumulation motives in the data set used (SCF). Hence, it is not possible to estimate a separate transfer wealth function using this data set. Since the dependent variable we intend to explain includes assets held for both life-cycle and transfer motives, the wealth equation must include determinants of both $W_{L}$ and $W_{B}$. Moreover, social security wealth is treated as an exogenous variable because households are unable to choose the level of most of

\footnotetext{
${ }^{9}$ We are of the opinion that the Survey of Consumer Finance is a better data source than the Family Expenditure Survey (FAMEX) to conduct an analysis of household wealth accumulation. The reasons for the choice of the SCF data are the following. First, it is widely believed that income is subject to under-reporting and expenditure is subject to over-reporting. Hence, a residual saving will be highly under-estimated if the FAMEX data are employed. Indeed, the study by Marr and McCready (1989), which uses FAMEX data, observed negative savings for most family types and age groups. Although we recognize the existence of measurement errors in the asset data, no adjustment has been made because any type of adjustment to the micro data based on aggregate household sector portfolio would be arbitrary. There exists an a priori reason to believe that measurement error in private net worth is uncorrelated with the birthplace. Since there is no motivation for the foreignborn to understate their wealth by a larger fraction than that of the Canadian-born given that the government tax system does not discriminate residents by their birthplace.

${ }^{10}$ Feldstein and Pellechio (1979) used average income for two consecutive years as a proxy for average lifetime earnings.
} 
their social security benefits in Canada. ${ }^{11}$ Incorporating the determinants of both life-cycle and transfer motives, we specify the following general form of the wealth equation:

$$
\ln W_{i}=f\left(L_{i}, \ln Y_{i}^{*}, \ln S S W_{i}, N C H L_{i}, X_{i}\right)+U_{i}
$$

where, $W=$ household fungible wealth or net worth, $L=$ stage of the household life cycle, $Y^{*}=$ normal earnings, $S S W=$ social security wealth, $N C H L=$ number of children, $X=\mathrm{a}$ vector of observable variables which influence the wealth-age relationship, $U=$ a random error which is distributed as $N\left(0, \sigma^{2}\right)$ and $i$ is an index for household.

The data used reports the husband as the head of household regardless of whether he is the principal earner in the family or not. Therefore, to measure the household's stage in the life cycle $(L)$ we include both the husband's and wife's ages. Social security wealth $(S S W)$ is defined as the present value of the future stream of benefits from public retirement benefits plans. ${ }^{12}$ The household's normal earnings are its predicted annual earnings corrected for its labour market participation probability. The vector $X$ includes the following control variables: (i) presence of unemployed (UNEMP), (ii) farm family (FARM), (iii) urban area (URBAN) and (iv) regional dummies (REGION). Observed wealth may differ from desired wealth due to unemployment. The dummy variable for unemployment captures this transitory effect as well as the effects of sustained differences in unemployment experience across households. Furthermore, the net worth of a farm family is expected to be greater than that of nonfarm family, ceteris paribus. Recognizing the nonlinearity of net worth in the stage of the life cycle and the potential impact of the number of children on transfer wealth, we express the specific form of the wealth equation as:

$$
\begin{aligned}
\ln W_{i}= & \alpha_{0}+\alpha_{1} \mathrm{Hage}_{i}+\alpha_{2} \mathrm{Hage}_{i}^{2}+\alpha_{3} \mathrm{Wage}_{i}+\alpha_{4} \mathrm{Wage}_{i}^{2}+\alpha_{5} \ln \left(Y_{i}^{*}\right) \\
& +\alpha_{6} \ln \left(S S W_{i}\right)+\alpha_{7} \mathrm{NCHL}_{i}+\alpha_{8} N C H L_{i}^{2} \\
& +\alpha_{9} \mathrm{UNEMP}_{i}+\alpha_{10} \mathrm{FARM}+\alpha_{11} \mathrm{URBAN}_{i}+\sum_{j=12}^{15} \alpha_{j} \mathrm{REGION}_{i j}+U_{i}
\end{aligned}
$$

where, Hage and Wage are the husband's age and wife's age respectively. The theoretically expected signs of the coefficients are:

(i) $\alpha_{1}, \alpha_{3}>0$ and $\alpha_{2}, \alpha_{4}<0$ (inverted $\mathrm{U}$-shape wealth-age profile);

(ii) $\alpha_{5}>0$ (positive income elasticity of asset demand);

(iii) $\alpha_{6} \leq$ or $>0$ (ambiguous effect of social security wealth);

(iv) $\alpha_{7}>0$ and $\alpha_{8}<0$ (transfer wealth increases at a decreasing rate with the number of children).

${ }^{11}$ We acknowledge that a portion of SSW may not be exogenous due to the existence of means test. Although a household can partially influence its earning by choosing hours worked but it has little or no control over market wages. Furthermore, a household has no control over social security rules. Thus we are of the opinion that entitlement to a significant part of SSW is beyond the control of a household.

${ }^{12}$ We recognize the problems in estimating the stock variable (SSW) from the flow variables (C/QPP, OAS, GIS). For the current workers we have estimated the stock variable from the estimates of the flow variables. In the absence of longitudinal data the second-best choice would be a quasipanel data set. However, it is not possible to construct a quasi-panel data set by pooling 1977 and 1984 SCFs because immigrant arrival periods are too broadly classified in the former survey. 
Since the distribution of wealth is skewed to the right, the log of net worth is employed as the dependent variable to avoid any potential heteroscedasticity. ${ }^{13}$

\section{The Data}

The empirical analysis is based on the 1977 and 1984 microdata files extracted from the Survey of Consumer Finances. Our primary variable, household net worth, is defined as total household assets minus total household debts. Assets include total deposits, cash in hand, Canada Savings Bond, stocks, RRSP (registered retirement savings plan), RHOSP (registered home-ownership savings plan), the market value of cars, trucks and vans (primarily for personal use), the market value of other vehicles, the market value of owner-occupied homes, equity in real estate other than owner occupied homes, and equity in a business, a farm or a profession. Assets do not include the imputed values for public or private pension rights, the family's human capital, or consumer durables other than automobiles.

The 1984 microdata file contains 14,029 households from which we extract a sample of 8,877 households with married couples. The 1977 microdata file includes a total of 12,734 households. A sample of 8,685 married couples is taken from the 1977 survey. Three types of families are excluded from the analysis: (i) special family units, (ii) unattached individuals and (iii) other families. ${ }^{14}$ Previous studies suggest that the wealth accumulation behaviour of low-wealth holders is significantly different from the rest of the population. King and Dicks-Mireaux (1982), Diamond and Hausman (1984) and Hubbard (1986) excluded the lowwealth holders from their analysis of household wealth accumulation based on the presumption that they face a liquidity constraint since they have little or no wealth to use as collateral to borrow money. Indeed, a preliminary analysis of our data set also suggests that the wealth-age profile of low-wealth holders does not follow an inverted U-shape. Thus, to facilitate our empirical investigation and follow conventions in the literature, households with less than $\$ 3,500$ of net worth are excluded. Next, Heckman's (1976) two-stage estimation procedure is used to avoid a potential selectivity bias resulting from sample truncation. ${ }^{15}$

\footnotetext{
${ }^{13}$ The distribution of wealth is highly skewed and a logarithmic transformation of this variable is desirable in this context in order to have a log-normally distributed dependent variable.

${ }^{14}$ The first category includes extremely wealthy families whose economic-demographic characteristics have been suppressed in the microdata tape. A significant proportion of the second and third types of families is headed by elderly women, perhaps widows. Permanent household income and hence the stock of net worth of these families depends on the lifetime income of their deceased husbands for which there exists no information in the data set. Furthermore, families under the title "other families" includes brother and sister living in the same dwelling, or grandparent living with grandson or granddaughter in the same house. The head of this type of family is not necessarily the principal earner and data are not available for the economic-demographic characteristics of other household members. Moreover, profiles of earnings and wealth for the "male-headed families with wife present" is expected to differ significantly from the "unattached" and "other families." Thus, the study is restricted to the focus on married couples.

${ }^{15}$ In the first stage, we estimate a probit model for low-wealth holders using the whole sample of married couples and obtain an estimate of the Inverse Mill's Ratio (IMR) for every household in the sample. The second stage uses the sub-sample of married couples with net worth $\geq \$ 3,500$, and yields OLS estimate of the net worth equation by including the inverse Mill's ratio as an additional regressor in equation (2). The probit results are available from the author on request.
} 
Table 2 reports some descriptive statistics for the estimation samples. The estimation sample for 1997 includes 7,017 Canadian-born and 1,668 foreign-born households. The 1984 sample includes 7,159 Canadian-born and 1,718 foreignborn households. In both sample years, the mean net worth of foreign-born households exceeds its Canadian-born counterpart. Moreover, mean net worth of Canadian-born households declined from 89 percent to 85 percent (of that of foreign-born households) over the period 1977-84. However, the ratio of Canadian-born median wealth to foreign-born median wealth remained around 71 percent in both sample years. On average, the foreign-born couples are 3 to 5 years older than the Canadian-born couples. Predicted annual earnings (or normal earnings) do not vary significantly by birthplace in 1977 . The 1984 sample exhibits slightly higher ( 4 percent) predicted earnings for Canadian-born households. Mean social security wealth of immigrants is higher than that of Canadianborn in both sample years despite the limited access of immigrants to one component (OAS) of social security benefits for the elderly. This finding correctly implies that, in the Canadian milieu, if a foreign-born person is ineligible for a portion of his/her pension, supplementary public funds are made available through other elements of the social security programme.

\section{EMP1RicAl RESUlts}

The analysis of wealth accumulation is conducted at two levels. First, we estimate a single wealth equation for the whole sample (the restricted model) under the assumption that the economic and demographic characteristics identically affect the savings behaviour of both the Canadian and foreign-born groups. A set of dummy variables indicating different periods of arrival in Canada is included in order to measure assimilation. In this case we calculate the time required for a newly arrived foreign-born household to catch up to the wealth level of a comparable Canadian-born household. Second, we offer an unrestricted model to relax the assumption of an identical parameter vector regardless of birthplace. Thus, under this model we estimate birth-status specific wealth accumulation equations.

\section{Restricted Wealth Equation}

The results of the restricted wealth-accumulation model are presented in Table 3. The coefficients for age and age squared are highly significant and confirm the existence of an inverted U-shaped wealth-age profile. The income elasticity of asset demand is 0.19 in 1977 and 0.15 in 1984, which implies a fall in savings propensity over the period 1977-84. The coefficients for children and children squared are significant and agree with Blinder's hypothesized signs for the transfer wealth, implying that the marginal transfer wealth declines with number of children. The coefficient for the social security wealth variable is insignificant for 1977 but significant for 1984. For the latter sample, public wealth was found to be an imperfect substitute for private wealth. More specifically, a dollar increase in social security in 1984 led to only a twelve cent reduction in private 
TABLE 2

Descriptive Statistics of the Estimation Samples

\begin{tabular}{|c|c|c|c|c|}
\hline \multirow[b]{2}{*}{ Variable } & \multicolumn{2}{|c|}{$\begin{array}{l}1977 \text { Sample Means } \\
\text { (Medians) }\end{array}$} & \multicolumn{2}{|c|}{$\begin{array}{l}1984 \text { Sample Means } \\
\text { (Medians) }\end{array}$} \\
\hline & $\begin{array}{l}\text { Canadian-Born } \\
\text { Households }\end{array}$ & $\begin{array}{l}\text { Foreign-Born } \\
\text { Households }\end{array}$ & $\begin{array}{l}\text { Canadian-Born } \\
\text { Households }\end{array}$ & $\begin{array}{c}\text { Foreign-Born } \\
\text { Households }\end{array}$ \\
\hline Net worth (In 1984 CAD\$) & $\begin{array}{r}88,179 \\
(45,725)\end{array}$ & $\begin{array}{r}99,556 \\
(64,379)\end{array}$ & $\begin{array}{r}98,874 \\
(55,410)\end{array}$ & $\begin{array}{r}116,611 \\
(78,697)\end{array}$ \\
\hline $\operatorname{Ln}$ (net worth) & 9.84 & 10.451 & 10.18 & 10.499 \\
\hline Husband's age & 43.7 & 48 & 45 & 50 \\
\hline (Husband's age) $^{2}$ & 2,135 & 2,512 & 2,265 & 2,695 \\
\hline Wife's age & 41 & 44 & 42 & 46 \\
\hline$(\text { Wife's age })^{2}$ & 1,887 & 2,193 & 2,016 & 2,354 \\
\hline Normal earnings (in 1984 & 21,018 & 21,233 & 24,365 & 23,382 \\
\hline CAD\$) & $(22,155)$ & $(20,916)$ & $(25,169)$ & $(24,506)$ \\
\hline Ln (normal earnings) & 9.69 & 9.688 & 9.616 & 9.567 \\
\hline Number of children & 1.58 & 1.41 & 1.24 & 1.31 \\
\hline${\text { (Number of children })^{2}}^{2}$ & 4.90 & 3.95 & 3.12 & 3.42 \\
\hline Social security wealth & 74,569 & 76,396 & 86,156 & 90,188 \\
\hline (in $1984 \mathrm{CAD}$ ) & $(69,730)$ & $(73,284)$ & $(80,627)$ & $(87,541)$ \\
\hline Ln (social security wealth) & 11.177 & 11.111 & 11.30 & 11.31 \\
\hline Presence of unemployed & 0.28 & 0.24 & 0.31 & 0.27 \\
\hline Farm family ${ }^{b}$ & 0.054 & 0.035 & 0.04 & 0.02 \\
\hline Urban family $^{c}$ & 0.46 & 0.73 & 0.57 & 0.82 \\
\hline \multicolumn{5}{|l|}{ Regional dummies $^{\mathbf{d}}$} \\
\hline Atlantic & 0.23 & 0.046 & 0.20 & 0.03 \\
\hline Quebec & 0.24 & 0.13 & 0.24 & 0.12 \\
\hline Prairies & 0.08 & 0.15 & 0.22 & 0.20 \\
\hline B.C. & 0.21 & 0.20 & 0.09 & 0.15 \\
\hline $\mathrm{IMG}^{\mathrm{e}}$ & & 0.192 & & 0.194 \\
\hline \multicolumn{5}{|l|}{$\begin{array}{l}\text { Dummy variables for immi- } \\
\text { grant arrival periods } \mathrm{s}^{\mathrm{f}}\end{array}$} \\
\hline IMGB46 & & 0.042 & & 0.028 \\
\hline IMGA46 & & 0.150 & & \\
\hline IMG66 & & & & 0.091 \\
\hline IMG71 & & & & 0.025 \\
\hline IMG76 & & & & 0.028 \\
\hline IMG81 & & & & 0.017 \\
\hline IMG84 & & & & 0.005 \\
\hline Sample Size & 7,017 & 1,668 & 7,159 & 1,718 \\
\hline
\end{tabular}

Notes: Data sources are Statistics Canada $(1977,1984)$.

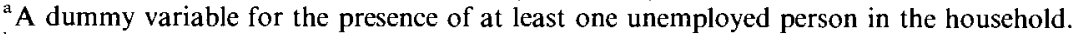

${ }^{\mathrm{b}}$ A dummy variable for farm family.

"The urban dummy variable takes value of unity if the household lives in an urban area with greater than 30,000 people and zero otherwise.

${ }^{\mathrm{d}}$ The reference category is Ontario.

${ }^{\mathrm{e}}$ The variable takes a value of unity if the household is headed by a foreign-born person and zero otherwise.

${ }^{f}$ The dummy variables for the arrival periods are: IMGB46 (before 1946); IMGA46 (after 1945); IMG66 (1946-1966); IMG71 (1967-1971); IMG76 (1972-1976); IMG81 (1977-1981); IMG84 (19811984). The mean of an immigrant arrival dummy in this table shows the proportion of the foreignborn cohort in the sample of all households, not in the sub-sample of all immigrant households. 
wealth. ${ }^{16}$ With all other included variables held constant, the presence of at least one unemployed person in the household reduces net worth by about 28 percent in both sample years. This large impact indicates that uncertainty, owing to spells of unemployment, affects household wealth accumulation. Location in Canada affects household wealth accumulation as farm households hold greater net worth than a nonfarm household and the regional effects on accumulation are also significant. Assimilation effects are also present in the results. For example, in the 1984 sample, the coefficients of the dummy variables for arrival periods (the omitted category is household headed by Canadian-born) suggest that the post1976 cohorts of immigrants' wealth holdings are about half that of comparable Canadian-born households. In addition, the wealth holdings of the 1972-76 immigrant arrival cohort was 26 percent lower than those born in Canada. Finally, wealth accumulation for the 1967-71 arrival cohort was not significantly different from comparable Canadian-born households. Thus, an immigrant household needs 15 years of settlement in Canada to catch up to the mean wealth level of a Canadian-born household with comparable economic-demographic characteristics. $^{17}$

\section{Unrestricted Equation: Canadian-born vis-à-vis Foreign-born Accumulation}

The birth-status specific wealth accumulation results appear in Table 4 . The coefficients for age and age squared are again consistent with the inverted Ushape wealth-age profile, a finding that remains robust across sample periods and birthplaces. The income elasticity of wealth is higher for Canadian-born households than that of foreign-born households in both years.

The interpretation of the coefficients of dummy variables is straightforward. The coefficient for the unemployment dummy is highly significant with a negative sign in both foreign-born and Canadian-born equations. This implies that the observed wealth holding for a household will be less than the desired level if there exists at least one unemployed person in the household. The farm family dummy has a positive effect and the corresponding coefficients are almost identical in magnitude for both groups in 1984 . The urban place of residence dummy obtains a statistically significant positive coefficient only in the 1984 foreign-born wealth equation. This result is due in part to involuntary accumulation in the form of capital gains in urban real estate. ${ }^{18}$

Table 5 reports the accumulation rates over the life cycle of households. The first derivative of the $\log$ of the wealth equation with respect to the stage of household life cycle $(L)$ yields the accumulation rate. ${ }^{19}$ The 1977 results indicate that a typical foreign-born household accumulates wealth at a faster rate than

${ }^{16}$ The displacement effect is derived from the wealth equation using the following formula:

Displacement Effect $=-0.1021(\bar{W} / \overline{S S W})$, where $W$ and

$\overline{S S W}$ represent mean net worth and mean social security wealth respectively.

${ }^{17}$ The difference between the sample year (1984) and the median value (1969) of the relevant arrival period gives us estimated years of residence (15) in Canada.

${ }^{18}$ Our 1984 data show that since foreign-born households hold a greater fraction of their wealth in real estate inclusive of owner-occupied home, their capital gains are larger than those of their Canadian-born counterparts.

${ }^{19}$ See notes below Table 5 for the computation procedure. 
TABLE 3

Houskhold Wealth Accumulation: Results for all Households Dependent variable: $\ln$ (net worth)

\begin{tabular}{|c|c|c|c|c|}
\hline & \multicolumn{2}{|c|}{1977 Results } & \multicolumn{2}{|c|}{1984 Results } \\
\hline & Coefficients & $(t \text {-statistics })^{\mathbf{a}}$ & Coefficients & $(t \text {-statistics })^{b}$ \\
\hline Constant & 6.1456 & $(17.26)$ & 7.592 & $(19.15)$ \\
\hline Husband's age & 0.07715 & $(6.83)$ & 0.06034 & $(5.93)$ \\
\hline Husband's age ${ }^{2}$ & -0.000618 & $(-5.53)$ & -0.00046 & $(-4.65)$ \\
\hline Wife's age & 0.028841 & $(2.82)$ & 0.0581 & $(5.81)$ \\
\hline Wife's age ${ }^{2}$ & -0.0001947 & $(-1.88)$ & -0.000415 & $(-4.17)$ \\
\hline Ln (normal earnings) & 0.18636 & $(8.64)$ & 0.1452 & $(9.74)$ \\
\hline Children & 0.14622 & $(7.88)$ & 0.1056 & $(4.82)$ \\
\hline Children $^{2}$ & -0.01885 & $(-6.09)$ & -0.0212 & $(-4.37)$ \\
\hline $\ln (\mathrm{SSW})$ & 0.00825 & $(0.43)$ & -0.1021 & $(-3.23)$ \\
\hline Presence of unemployed & -0.2666 & $(-7.74)$ & -0.2826 & $(-10.90)$ \\
\hline Farm family & 1.1965 & $(24.20)$ & 1.186 & (20.28) \\
\hline Urban family & 0.02115 & $(0.72)$ & 0.00903 & $(0.321)$ \\
\hline Atlantic & -0.5069 & $(-14.35)$ & -0.2767 & $(-7.72)$ \\
\hline Quebec & -0.5243 & $(-16.24)$ & -0.2621 & $(-8.48)$ \\
\hline Prairies & -0.0482 & $(-1.48)$ & -0.0805 & $(-2.57)$ \\
\hline B.C. & 0.0941 & $(2.29)$ & 0.1370 & $(3.52)$ \\
\hline IMGB46 & 0.00477 & $(0.08)$ & 0.06070 & $(0.91)$ \\
\hline IMGA46 & -0.0884 & $(-2.64)$ & & \\
\hline IMG66 & & & 0.1716 & $(4.48)$ \\
\hline IMG71 & & & 0.0434 & $(0.61)$ \\
\hline IMG76 & & & -0.2635 & $(-3.74)$ \\
\hline IMG8] & & & -0.5379 & $(-5.89)$ \\
\hline IMG84 & & & -0.5046 & $(-2.90)$ \\
\hline $\mathrm{IMR}^{\mathbf{b}}$ & 0.0168 & $(0.11)$ & -0.0911 & $(-0.64)$ \\
\hline $\bar{R}^{2}$ & \multicolumn{2}{|c|}{0.30} & \multicolumn{2}{|c|}{0.30} \\
\hline$F$-statistic & \multicolumn{2}{|c|}{179.4} & \multicolumn{2}{|c|}{154.1} \\
\hline [Degrees of freedom] & \multicolumn{2}{|c|}{$[18,7,464]$} & \multicolumn{2}{|c|}{$[22,7,852]$} \\
\hline $\begin{array}{l}\text { Standard error corrected for } \\
\text { selection }\end{array}$ & \multicolumn{2}{|c|}{0.9373} & \multicolumn{2}{|c|}{0.9402} \\
\hline Selected sample & \multirow{2}{*}{\multicolumn{2}{|c|}{$\begin{array}{l}7,483 \\
1,202\end{array}$}} & \multicolumn{2}{|c|}{7,875} \\
\hline $\begin{array}{l}\text { Excluded sub-sample of low } \\
\text { wealth holders }\end{array}$ & & & \multicolumn{2}{|c|}{1,002} \\
\hline
\end{tabular}

${ }^{a}$ The figures in parentheses are the corresponding heteroskedisticity-consistent $t$-statistics, computed as the ratios of the coefficient estimates to the square roots of the respective diagonal elements of Greene's (1981) estimated asymptotic covariance matrix of coefficients.

${ }^{\mathrm{b}}$ Inverse Mill's Ratio.

the Canadian-born prior to age 50. After age 50, the results reverse. In sharp contrast, the 1984 results show a higher rate of accumulation for Canadian-born households at every stage of the life cycle than that of foreign-born households.

Next, we focus on the marginal transfer wealth resulting from an increase in the number of children. Given that the wealth equation is semi-logarithmic in children and children squared and the number of children is a discrete variable, the marginal transfer wealth $(\Delta W / \Delta$ children) functions for 1984 , based on Table 4 , can be expressed as:

$$
\begin{aligned}
& \text { Marginal transfer wealth }\left.\right|_{\text {Canadian born }} \\
& \quad=\left[0.0981-0.0196\left\{(\text { children })^{2}-(\text { children }-1)^{2}\right\}\right] W
\end{aligned}
$$


TABLE 4

Household Wealth Accumulation by Birth Place

Dependent variable: In (net worth)

\begin{tabular}{|c|c|c|c|c|}
\hline & \multicolumn{2}{|c|}{1977 Results } & \multicolumn{2}{|c|}{1984 Results } \\
\hline & $\begin{array}{l}\text { Canadian-Born } \\
\text { Households }\end{array}$ & $\begin{array}{l}\text { Foreign-Born } \\
\text { Households }\end{array}$ & $\begin{array}{l}\text { Canadian-Born } \\
\text { Households }\end{array}$ & $\begin{array}{c}\text { Foreign-Born } \\
\text { Households }\end{array}$ \\
\hline Constant & $\begin{array}{r}6.3212 \\
(14.62)\end{array}$ & $\begin{array}{r}5.4798 \\
(7.48)\end{array}$ & $\begin{array}{l}7.2692 \\
(12.21)\end{array}$ & $\begin{array}{l}8.1254 \\
(11.91)\end{array}$ \\
\hline Husband's age & $\begin{array}{r}0.072164 \\
(5.58)\end{array}$ & $\begin{array}{r}0.1069 \\
(4.42)\end{array}$ & $\begin{array}{r}0.0570 \\
(5.07)\end{array}$ & $\begin{array}{r}0.0737 \\
(2.90)\end{array}$ \\
\hline Husband's age $^{2}$ & $\begin{array}{r}-0.00059 \\
(-4.62)\end{array}$ & $\begin{array}{r}-0.00083 \\
(-3.45)\end{array}$ & $\begin{array}{r}-0.00044 \\
(-3.99)\end{array}$ & $\begin{array}{r}-0.00057 \\
(-2.44)\end{array}$ \\
\hline Wife's age & $\begin{array}{r}0.0278 \\
(2.42)\end{array}$ & $\begin{array}{r}0.0357 \\
(1.57)\end{array}$ & $\begin{array}{r}0.0577 \\
(5.15)\end{array}$ & $\begin{array}{r}0.0487 \\
(2.15)\end{array}$ \\
\hline Wife's age ${ }^{2}$ & $\begin{array}{r}-0.00016 \\
(-1.34)\end{array}$ & $\begin{array}{r}-0.00035 \\
(-1.53)\end{array}$ & $\begin{array}{r}-0.00039 \\
(-3.49)\end{array}$ & $\begin{array}{r}-0.00038 \\
(-1.75)\end{array}$ \\
\hline Ln (normal earning) & $\begin{array}{r}0.1917 \\
(8.20)\end{array}$ & $\begin{array}{r}0.1568 \\
(2.75)\end{array}$ & $\begin{array}{r}0.1552 \\
(9.11)\end{array}$ & $\begin{array}{r}0.0754 \\
(2.21)\end{array}$ \\
\hline Children & $\begin{array}{r}0.1417 \\
(7.03)\end{array}$ & $\begin{array}{r}0.1627 \\
(3.14)\end{array}$ & $\begin{array}{r}0.0981 \\
(4.00)\end{array}$ & $\begin{array}{r}0.1393 \\
(2.75)\end{array}$ \\
\hline Children $^{2}$ & $\begin{array}{r}-0.0185 \\
(-5.69)\end{array}$ & $\begin{array}{r}-0.0169 \\
(-1.62)\end{array}$ & $\begin{array}{r}-0.0196 \\
(-3.59)\end{array}$ & $\begin{array}{r}-0.0272 \\
(-2.52)\end{array}$ \\
\hline $\operatorname{Ln}(\mathrm{SSW})$ & $\begin{array}{r}0.0020 \\
(0.07)\end{array}$ & $\begin{array}{r}0.0078 \\
(0.30)\end{array}$ & $\begin{array}{r}-0.0827 \\
(-1.43)\end{array}$ & $\begin{array}{r}-0.1054 \\
(-2.29)\end{array}$ \\
\hline Presence of unemployed & $\begin{array}{r}-0.2621 \\
(-6.82)\end{array}$ & $\begin{array}{r}-0.3084 \\
(-3.98)\end{array}$ & $\begin{array}{l}-0.2851 \\
(-10.15)\end{array}$ & $\begin{array}{r}-0.2257 \\
(-3.26)\end{array}$ \\
\hline Farm family & $\begin{array}{l}1.1589 \\
(21.80)\end{array}$ & $\begin{array}{r}1.3669 \\
(9.98)\end{array}$ & $\begin{array}{r}1.1829 \\
(19.25)\end{array}$ & $\begin{array}{r}1.1741 \\
(6.21)\end{array}$ \\
\hline Urban family & $\begin{array}{r}0.0180 \\
(0.55)\end{array}$ & $\begin{array}{r}0.0516 \\
(0.76)\end{array}$ & $\begin{array}{r}-0.0142 \\
(-0.48)\end{array}$ & $\begin{array}{r}0.1634 \\
(2.07)\end{array}$ \\
\hline Atlantic & $\begin{array}{l}-0.5236 \\
(-13.78)\end{array}$ & $\begin{array}{r}-0.2117 \\
(-1.66)\end{array}$ & $\begin{array}{r}-0.2950 \\
(-7.79)\end{array}$ & $\begin{array}{r}0.0521 \\
(1.63)\end{array}$ \\
\hline Quebec & $\begin{array}{l}-0.5318 \\
(-14.85)\end{array}$ & $\begin{array}{r}-0.4815 \\
(-5.89)\end{array}$ & $\begin{array}{r}-0.2950 \\
(-7.68)\end{array}$ & $\begin{array}{r}-0.2878 \\
(-3.57)\end{array}$ \\
\hline Prairies & $\begin{array}{r}-0.0315 \\
(-0.84)\end{array}$ & $\begin{array}{r}-0.0997 \\
(-1.46)\end{array}$ & $\begin{array}{r}0.0805 \\
(2.27)\end{array}$ & $\begin{array}{r}0.0705 \\
(1.02)\end{array}$ \\
\hline B.C. & $\begin{array}{r}0.0791 \\
(1.62)\end{array}$ & $\begin{array}{r}0.1320 \\
(1.70)\end{array}$ & $\begin{array}{r}0.1335 \\
(2.88)\end{array}$ & $\begin{array}{r}0.1663 \\
(2.30)\end{array}$ \\
\hline IMGA46 & & $\begin{array}{r}-0.1359 \\
(-1.55)\end{array}$ & & \\
\hline IMG66 & & & & $\begin{array}{r}0.0889 \\
(0.98)\end{array}$ \\
\hline 1MG71 & & & & $\begin{array}{r}-0.0514 \\
(-0.40)\end{array}$ \\
\hline IMG76 & & & & $\begin{array}{r}-0.3583 \\
(-2.56)\end{array}$ \\
\hline IMG81 & & & & $\begin{array}{r}-0.6402 \\
(-4.25)\end{array}$ \\
\hline IMG84 & & & & $\begin{array}{r}-0.5884 \\
(-2.47)\end{array}$ \\
\hline IMR & $\begin{array}{r}-0.0246 \\
(-0.14)\end{array}$ & $\begin{array}{r}0.4069 \\
(1.20)\end{array}$ & $\begin{array}{r}-0.1052 \\
(-0.78)\end{array}$ & $\begin{array}{r}-0.2554 \\
(-0.67)\end{array}$ \\
\hline$\overline{\bar{R}^{2}}$ & 0.31 & 0.24 & 0.31 & 0.26 \\
\hline$F$-Statistic & 171.9 & 282.5 & 175.2 & 25.7 \\
\hline [Degrees of freedom] & {$[16,5,986]$} & {$[17,1,479]$} & {$[16,6,324]$} & {$[21,1,512]$} \\
\hline $\begin{array}{l}\text { Standard error } \\
\text { corrected for selection }\end{array}$ & 0.9322 & 0.9714 & 0.9345 & 0.9636 \\
\hline Selected sample & 5,986 & 1,497 & 6,341 & 1,534 \\
\hline $\begin{array}{l}\text { Excluded sub-sample of } \\
\text { low wealth holders }\end{array}$ & 1,031 & 171 & 818 & 184 \\
\hline
\end{tabular}

Note: The figures in parentheses are the corresponding heteroskedisticity-consistent $t$-statistics, computed as the ratios of the coefficient estimates to the square roots of the respective diagonal elements of Greene's (1981) estimated asymptotic covariance matrix of coefficients. 
Marginal transfer wealth $\left.\right|_{\text {Foreign-born }}$

$$
=\left[0.1393-0.0272\left\{(\text { children })^{2}-(\text { children }-1)^{2}\right\}\right] W
$$

Similarly, one can derive the marginal transfer wealth results for 1977 . For both the 1977 and 1984 samples, foreign-born households exhibit a strong transfer motive within the family network. In 1984, for the first child, marginal transfer wealth was $\$ 13,072$ for a typical foreign-born household and $\$ 7,761$ for a Canadian-born household. ${ }^{20}$ Using the above pair of marginal transfer wealth functions, we derive the increment in transfer wealth with respect to the number of children for different wealth levels. These results are depicted in Table 6. The results are consistent with the hypothesis that transfer wealth increases with household net worth and increases at a decreasing rate with the number of children. For both sample years, foreign-born households show a stronger transfer motive than Canadian-born households. However, for the 1984 sample, the size of the marginal transfer wealth is negligible after the second child.

The effect of social security on household net worth accumulation differs by period. For the 1977 sample, the effect of social security wealth on household net worth is not significantly different from zero. The 1984 results suggest that one additional dollar of social security wealth displaces fourteen cents of net wealth for the foreign-born and nine cents for the Canadian-born household (see Table 7). This latter finding is consistent with the life-cycle literature.

\section{Summary and Conclusions}

We conclude with a summary of the major findings on household wealth accumulation by birth status. First, the empirical results are compatible with the notion of an inverted U-shaped wealth-age profile. The shape of the wealth-age profile however, differs by birth status. The 1977 results indicate that, faced with the uncertainty in a new country of residence-Canada-immigrants accumulate wealth at a higher rate than the Canadian-born until age 49. Also, given limited access to old age security benefits and little or no parental transfer wealth prior to arrival, foreign-born households dissipate wealth faster than the Canadianborn to finance their retirement consumption. The foreign-born wealth profile has a more pronounced inverted $U$-shape than the Canadian-born profile. The 1984 results reveal that after age 24 , compared to a Canadian-born household, a foreign-born household accumulates wealth at a lower rate over the working life span and also dissipates wealth at a higher rate during retirement.

The transfer motive for the foreign-born is stronger in both 1977 and 1984 than that of the Canadian-born. Canada's social security programme also has a differential impact by birth status. Immigrants exhibit a slightly greater displacement effect on personal wealth from social security wealth than the Canadianborn in 1984. The net effect of public social security programmes on national

\footnotetext{
${ }^{20}$ These figures are obtained by substituting the birth-status specific mean net worth in the relevant marginal transfer wealth function. Marginal transfer wealth depends on number of children and net worth. To isolate the pure effect of children on transfer wealth, the mean net worth $(\$ 102,307)$ for the whole sample was also used to compute the marginal propensity to transfer. The results indicate that for the first child, marginal transfer wealth was $\$ 11,469$ for a foreign-born household and $\$ 8,031$ for a Canadian-born household.
} 
TABLE 5

Household Wealth Accumulation Rates by Birth Place (in percentage)

\begin{tabular}{lcccc}
\hline \hline $\begin{array}{l}\text { Age Group } \\
\text { (Husband's Age) }\end{array}$ & \multicolumn{2}{c}{ Canadian-born households } & \multicolumn{2}{c}{ Foreign-born households } \\
\hline & 1977 Sample & 1984 Sample & 1977 Sample & 1984 Sample \\
\hline Below 25 & 7.030 & 7.798 & 9.093 & 8.042 \\
$25-29$ & 6.284 & 7.086 & 8.035 & 6.204 \\
$30-34$ & 5.493 & 6.320 & 6.896 & 5.441 \\
$35-39$ & 4.696 & 5.522 & 5.746 & 4.736 \\
$40-44$ & 3.899 & 4.732 & 4.597 & 3.942 \\
$45-49$ & 3.085 & 3.940 & 3.416 & 3.140 \\
$50-54$ & 2.277 & 3.103 & 2.248 & 2.359 \\
$55-59$ & 1.475 & 2.267 & 1.088 & 1.489 \\
$60-64$ & 0.680 & 1.420 & -0.059 & 0.634 \\
$65-69$ & -0.110 & 0.657 & -1.195 & -0.112 \\
$70-74$ & -0.902 & -0.119 & -2.336 & -0.813 \\
$75-79$ & -1.715 & -0.879 & -3.514 & -1.507 \\
80 and above & & -1.663 & & -2.314 \\
\hline
\end{tabular}

Source: Table 4.

${ }^{\mathrm{a}}$ The one-year rate of accumulation is defined as: $d W / W=\left(\hat{\alpha}_{1}+2 \hat{\alpha}_{2} M_{i}\right)+$ $\left(\hat{\alpha}_{3}+2 \hat{\alpha}_{4} F_{i}\right)$, where, $M_{i}$ is the median age of husbands in group $i, \hat{\alpha}_{1}$ and $\hat{\alpha}_{2}$ are the coefficients of the husband's age and age ${ }^{2}$ respectively for the wealth accumulation equation, $F_{i}$ is the median age of wives whose husbands belong to age group $i, \hat{\alpha}_{3}$ and $\hat{\alpha}_{4}$ are the coefficients of the wife's age and age ${ }^{2}$ respectively.

TABLE 6

Marginal Transfer Wealth with Respect to the Number of

CHILDREN

(in 1984 dollars)

\begin{tabular}{|c|c|c|c|c|c|c|}
\hline \multirow[b]{3}{*}{ Net Worth } & \multicolumn{3}{|c|}{ Canadian-Born Households } & \multicolumn{3}{|c|}{ Foreign-Born Households } \\
\hline & \multicolumn{3}{|c|}{ Number of Children } & \multicolumn{3}{|c|}{ Number of Children } \\
\hline & 1 & 2 & 3 & 1 & 2 & 3 \\
\hline \multicolumn{7}{|l|}{1977 Results } \\
\hline $\begin{array}{l}\$ 25,000 \\
\$ 100,000 \\
\$ 500,000\end{array}$ & $\begin{array}{r}3,080 \\
12,320 \\
61,600\end{array}$ & $\begin{array}{r}2,155 \\
8,620 \\
43,100\end{array}$ & $\begin{array}{r}1,230 \\
4,920 \\
24,600\end{array}$ & $\begin{array}{r}3,645 \\
14,580 \\
72,900\end{array}$ & $\begin{array}{r}2,800 \\
11,200 \\
56,000\end{array}$ & $\begin{array}{r}1,955 \\
7,800 \\
39,100\end{array}$ \\
\hline \multicolumn{7}{|l|}{1984 Result, } \\
\hline $\begin{array}{l}\$ 25,000 \\
\$ 100,000 \\
\$ 500,000\end{array}$ & $\begin{array}{r}1,963 \\
7,800 \\
39,250\end{array}$ & $\begin{array}{r}983 \\
3,930 \\
19,650\end{array}$ & $\begin{array}{r}3 \\
10 \\
50\end{array}$ & $\begin{array}{r}2,803 \\
11,210 \\
56,050\end{array}$ & $\begin{array}{r}1,443 \\
5,770 \\
28,850\end{array}$ & $\begin{array}{r}83 \\
330 \\
1,650\end{array}$ \\
\hline
\end{tabular}

Source: Table 4 and equations (3) and (4).

savings was positive in 1984 since the displacement effect of social security wealth is less than unity for both groups. Thus, our 1984 results suggest that public and private savings are not perfect substitutes due to the induced retirement effect.

These results lead to the major policy conclusion that this wealth effect should be recognized in Canada's immigrant selection criteria. For example, the post-1977 immigration policy switched the composition of immigrants from the 
TABLE 7

Effects of Social Security Wealth on Household Wealth: 1984

RESULTS

(in 1984 dollars)

\begin{tabular}{lccc}
\hline \hline & $\begin{array}{c}\text { Mean Net Worth } \\
\text { (Median) }\end{array}$ & $\begin{array}{c}\text { Mean SSW } \\
\text { (Median) }\end{array}$ & $\begin{array}{c}\text { Effect of a Dollar } \\
\text { Increase in SSW on } \\
\text { Private Net Worth* }\end{array}$ \\
\hline All households & $102,306.8$ & $86,936.3$ & -0.12 \\
Canadian-born & $(59,244)$ & $(82,198)$ & -0.09 \\
households & $98,873.9$ & $86,155.9$ & -0.14 \\
Foreign-born & $(55,410)$ & $(80,627)$ & \\
households & $116,611.4$ & $90,187.8$ & $(87,541)$ \\
\hline
\end{tabular}

Source: Table 3.

Note: Evaluated at mean net worth and mean social security wealth.

economic class to the family class. The observed reduced foreign-born accumulation rates in 1984 may be a partial outcome of this policy change.

The limitations of this study are few but non-trivial. First, due to lack of data, this study did not include private pension wealth as an exogenous variable in the wealth accumulation function. Second, if the productivity characteristics and preferences of households are unstable due to cohort or period effects, then the wealth -age profile and assimilation results may change. Finally, if wealthy individuals live longer, then the observed slower rate of wealth dissipation during retirement does not necessarily imply that the prediction of the life-cycle model is contradicted by our observation.

\section{REFERENCES}

Auerbach, A. J. and L. J. Kotlikoff, Dynamic Fiscal Policy, Cambridge University Press, Cambridge, 1987.

Blinder, A. S., A model of Inherited Wealth, Quarterly Journal of Economics, 87, 608-626, 1973.

, R. H. Gordon, and D. E. Wise, Social Security, Bequests and the Life Cycle Theory of Saving: Cross-sectional Tests, in F. Modigliani and R. Hemming, (eds.), The Determinants of National Saving, 89-122, Macmillan, London, 1983.

Boyle, P. and J. Murray, Social Security and Private Saving in Canada, Canadian Journal of Economics, 12, No. 3, 446-67, 1979.

Burbidge, J. and A. L. Robb, Evidence on Wealth-age Profiles in Canadian Cross Section Data, Canadian Journal of Economics, 18, No. 4, 854-75, 1985.

Coulson, R. G. and D. J. DeVoretz, Human Capital Content of Canadian Immigrants: 1967-1987, Canadian Public Policy, 19, No. 4, 357-66, 1993.

Davies, J., Uncertain Life Time, Consumption and Dissaving in Retirement, Journal of Political Economy, 89, 56I-77, 1981 .

DeVoretz, D. J., Immigration and the Canadian Labour Market, in S. Globerman, (ed.), Immigration Dilemma, 173-95, Fraser Institute, Vancouver, 1993.

Diamond, P. A. and J. A. Hausman, Individual Retirement and Savings Behaviour, Journal of Public Economics, 23, (1/2), 81-114, 1984.

Feldstein, M. S., Social Security, Induced Retirement and Aggregate Capital Accumulation, Journal of Political Economy, 82, No. 5, 905-26, 1974.

-, Social Security and Private Savings: International Evidence in an Extended Life-cycle Model, in M. S. Feldstein and R. Inman, (eds.), The Economics of Public Services, Macmillan, London, 1977.

and A. Pellechio, Social Security and Household Wealth Accumulation: New Microeconomic Evidence, The Review of Economics and Statistics, 61, No. 3, 361-68, 1979. 
Heckman, J., The Common Structure of Statistical Models of Truncation, Sample Selection and Limited Dependent Variables and a Simple Estimator for Such Models, Annals of Economic and Social Measurement, 5, No. 4, 475-92, 1976.

Hubbard, G. R., Pension Wealth and Individual Saving: Some New Evidence, Journal of Money, Credit and Banking, 18, No. 2, 167-78, 1986.

Hurd, M. D., Mortality Risk and Bequests, Econometrica, 57, No. 4, 779-813, 1989.

King, M. A. and L-D. L. Dicks-Mireaux, Asset Holdings and the Life Cycle, Economic Journal, 92 , No. 366, 247-67, 1982.

Marr, W. L. and D. J. McCready, The Effects of Demographic Structure on Expenditure Patterns in Canada, Discussion Paper No. 89.A.1, The Institute of Research on Public Policy, Ottawa, 1989.

Modigliani, F., The Role of Intergenerational Transfers and the Life Cycle Saving in the Accumulation of Wealth, The Journal of Economic Perspectives, 2, No. 2, 15-40, 1988.

Robb, A. L. and J. B. Burbidge, Consumption, Income and Retirement, Canadian Journal of Economics, 22, No. 3, 522-42, 1989.

Shafer, J. R., J. Elmeskov, and W. Tease, Saving Trends and Measurement Issues, Scandinavian Journal of Economics, 94, No. 2, 155-75, 1992.

Shamsuddin, Abul F. M., Wealth Accumulation and Portfolio Selection Behaviour of Canadian and Foreign-born Households, Ph.D. dissertation, Simon Fraser University, Vancouver, 1993.

-, The Double-Negative Effect on the Earnings of Foreign-Born Females in Canada, Working Paper Series No. 97-03, Research on Immigration and Integration in the Metropolis (RIIM), Simon Fraser University, Vancouver, 1997.

Statistics Canada, Income (1976), Assets and Debts (1977) of Economic Families and Unattached Individuals, Survey of Consumer Finance, Household Survey Division, Ottawa, 1977.

, Income (1983), Assets and Debts (1984) of Economic Families and Unattached Individuals, Survey of Consumer Finance, Household Survey Division, Ottawa, 1984. 